\title{
The Advancement of Demographics Learning Tools
}

\author{
Pargaulan Siagian, Faiz Ahyaningsih, Glory Indira Diana Purba \\ Fmipa Unimed.
}

\begin{abstract}
This study is aimed at producing a learning tools to a lecturing program in form of : lectures unit (SAP), Lecturing Text Books (BTPM), and Demography lecturing attendant activity sheet (LKPDM), and the ability assessment of attendant program (PKHPM) it is all in order to ensure demography subject be more valid, practical, and effective with in a learning model aided with Think, Pair and Share (TPS) and data based. The teaching material matter to Demography Techniques subject to develop such as; Introduction, base source of statistics, collecting and data processing of demographic, size population, population distribution of geographic region, population distribution of geographic area, the age composition and gender, composition of race and ethnic, change of population, education and characteristics of economic, mortality, life table, demography of health, birth-rate bases to census and survey, population growth, international migration, internal migration and short-time mobility, and population forecast. The process how to implement perhaps prepare an attending tools component either : to plan an attendant unit (SAP), attendance book of demographic (BBKD), and attendance activity sheet (LKPM), and ability test of Demographic study (TKHPD), and ability assessment of attendant program (PKHPM) to be distributed over all Lecturers Team on Mathematics Department of FMIPA Unimed.
\end{abstract}

Keywords : Advancement

\section{INTRODUCTION}

\subsection{The Background of the Topic}

According to population census of 2010, the Indonesian demography had total population some 237,641,326 million persons, resulted in this nation as the most greatest $4^{\text {th }}$ of population over the world. The amount is estimated going to rise up as projected for 2025 the Indonesian population amounting 275 million people, and it may achieve 305 million people for 2035. Java island shall be one of the most crowded regions with more than 107 million people live on the region with width as large as New York. Indonesia has the most variously cultures and local tongues

The planet we live with has 195 nations of total population amounting 7,405,107,650 people (according to CIA World Factbook for 2017). Chine nation is the first with the most population greatest over the world totally own population of 1.38 million people noted preciously $1,379,302.771$ people. The amount is constitute of $18.6 \%$ of all the world population. Still to the second rate, noted India with total population of $1,281,935,911$ people or around $17.3 \%$ of whole world population. United States runs to the third rate with total population of 326,625,791 people (around $4.4 \%$ of whole world population). 
The following is the list 10 nations with total own population as below.

Table 1: List of 10 nations with total Population in the most

\begin{tabular}{|c|c|c|c|c|}
\hline No & Nation & Population Rate & Date & \% of World Population \\
\hline $\mathbf{1}$ & $\begin{array}{c}\text { People's Republic of } \\
\text { China }\end{array}$ & 1.396 .390 .000 & May 9, 2019 & $18.5 \%$ \\
\hline $\mathbf{2}$ & India & 1.341 .410 .000 & May 9, 2019 & $17.8 \%$ \\
\hline $\mathbf{3}$ & United States & 330.781 .000 & May 9, 2019 & $4.38 \%$ \\
\hline $\mathbf{4}$ & Indonesia & 265.015 .300 & 1 July 2018 & $3.51 \%$ \\
\hline $\mathbf{5}$ & Pakistan & 215.525 .000 & May 9, 2019 & $2.85 \%$ \\
\hline $\mathbf{6}$ & Brazil & 211.295 .000 & May 9, 2019 & $2.8 \%$ \\
\hline $\mathbf{7}$ & Nigeria & 193.392 .517 & July 1, 2016 & $2.56 \%$ \\
\hline $\mathbf{8}$ & Bangladesh & 166.521 .000 & May 9, 2019 & $2.2 \%$ \\
\hline $\mathbf{9}$ & Russian & 146.877 .088 & Jan 1, 2018 & $1.94 \%$ \\
\hline $\mathbf{1 0}$ & Mexico & 126.577 .691 & Jan 1, 2019 & $1.68 \%$ \\
\hline \multicolumn{4}{|c|}{} \\
\hline
\end{tabular}

The following is the birth-rate list on variously nations over the world. The information as below refers to a research result of UN and CIA World Factbook. The information below is based on birth-rate per thousand population of interval time, year, or a certain period.

\subsection{The Purpose and Uses of Demography}

The main objective in this matter is to observe the quantity and population distribution in a certain area, also to reveal its growth in the past, got decreased and spreading out properly with data available. Evolving casualty correlation between growing population rate to variously social organization aspects. Forecasting population growth in future and its consequences possibility. The uses of demography is playing a very important role in planning of development, more complete and with data accurate of population available should accelerate and simplify to plan the development as well as.

\subsection{The Formulation of the Problem}

1.1.1 How to assess validity of learning tools of Demographics as improved up on FMIPA Universitas Negeri Medan, Department of Mathematics?

1.1.2 How to make more practical the learning tools of Demographics as improved up on FMIPA Universitas Negeri Medan, Department of Mathematics?

1.1.3 How to make more effective the learning tools of Demographics as improved up on FMIPA Universitas Negeri Medan, Department of Mathematics. ?

As young generation for future leader is worth to submit them the values, cultures, basic knowledge, mainly demography as a development human agent for they shall receive the development relay in leading position, also in middle and in rear part of public, it should be ready to hand-over responsibility to lead this nation for future. How to improve quality of human resources then get a golden generation gained for 2035, noted that a demographics learning should be processed with accurate data and contextual.

In order to have Bruner cognitive development theory applied and to understand concepts in abstract, is highly required representative that human sense may catch in. There are three representative phases that can be taken by a learning in population and environmental, namely : 
a) Enactive phase, with a learning stage where information or knowledge must be observed actively by students by using a concrete objects.

b) Econics phase, it is a learning stage where the knowledge might be presented in visual vision (picture, schema, diagram, graphic, table, etc) as it may illuminate a concrete situation existed empirically.

c) Symbolical phase, it is a stage whereby knowledge is presented in a symbolicabstract, either verbal symbols, with mathematics symbols or others abstract symbols.

\section{LITERATURE REVIEW AND ROAD MAP OF RESEARCH 2.1 Cooperative Learning Type Think Pair and Share}

The uses of cooperative learning with a think pair and share type method by story telling may lead to more attractive and encourage the student attending the class with story telling. The second stage (pair) to use is a paired story-telling technique. The paired Story-telling teaching method has been established as interactive approach among those students, teachers, and material of attendance (Lie, 2004). With this method, the students can share in paired mainly to solve the difficulties by telling in class-room. By share, every body can show in participation each other. Think-Pair-Share as one of types in a cooperative learning, and it offer opportunity to every student to think, in pair or to work by partner, share, and help each other with it then may enrich variation in a learning model be attractive, to please, to improve activity and to work each other.

Thin-Pair Share is one of cooperative learning types was invented by Frank Lyman, etc from Maryland University in 1985, and known as one of structures. Think-pair share persistently spare time to all students to think and respond one and another. Think-pair share also give them opportunity to work alone and in cooperative. Another benefit is to give participation optimally to all students.

Several advantages of the learning tools as above indicated that tools is highly important to prepare before starting the learning process. The learning tools may facilitate the students to be actively participating to improve one-self potential become have competence. So, a teacher is obliged to guide all students in conducting variously activities according to own potential as a competence required.

Still existed weakness, this indicated that quality of learning tool available not well yet. And it refers to a reality that tools as had been developed by teacher not been ever test on its validity, its practical or effectiveness, with which this tree points are highly required as criterion.

Validity aspect covering two matters namely validity of content and validity of construct (Rochmad, 2012: 69). Validity of content is based on theories when arrange its learning tools, while validity of construct is based on interaction in components in a learning tools. Still, aspect of practical in the tools is done to see whether component of tools have been done whole or not. Further, aspect of effectiveness should be viewed from its achievement, since this aspect can be seen from completeness in all result of study, activity of student as long as learning and their capability m Mathematics (Rochmad, $2012: 71)$. The tools of attendance as developed by lecturer is not tested its effectiveness yet. 
For the learning tools planned to be executed inside class-room that learning tools as oriented PBM model expected as alternative to generate a learning properly and it should improve their ability of thinking mainly on demographics and push them to study autonomous. Based on above mentioned, the main objective of this study are : (1) how to promote validity and effectiveness of learning tools, (2) how to improve their thinking ability with the result in demographics study and to their autonomous up there using a learning tools as advancement.

\subsection{The Learning Model Syntax of Think, Pair and Share}

The syntax of learning model with think pair, share cooperative type comprising of five stages, in three stages as main phase with its specific characteristics namely think, pair, and share. The following is the stages to have learning model with thin pair share type.

Table 2: The Steps in making a Think Pair and Share Type

\begin{tabular}{|l|l|}
\hline \multicolumn{1}{|c|}{ The Steps } & \multicolumn{1}{c|}{ The Learning Activity } \\
\hline $\begin{array}{l}\text { Stage-1 : } \\
\text { Introduction }\end{array}$ & $\begin{array}{l}\text { Teacher explain the game rule and its time limit to each activity to } \\
\text { motivate the student take part in activity of solving problem. Also } \\
\text { mention competency point should gain. }\end{array}$ \\
\hline $\begin{array}{l}\text { Step-2 } \\
\text { Think }\end{array}$ & $\begin{array}{l}\text { Teacher demonstrates simply in order to get a base concept and know } \\
\text { better. On this stage, the student is given "Think time" by teacher, } \\
\text { mainly to gain respond individually on the question given. While } \\
\text { considering, the teacher should understand the students' basic } \\
\text { knowledge while answer the questions given. } \\
\text { The students should make own respond individually on LKS sheet }\end{array}$ \\
\hline $\begin{array}{l}\text { Step -3 } \\
\text { Pair }\end{array}$ & $\begin{array}{l}\text { S Process of think pair share started when the student has already pair } \\
\text { each. Then, teacher may ask that each student get pair in fellow-chair. } \\
\text { The student discuss immediately about the answer to the question has } \\
\text { been given. }\end{array}$ \\
\hline $\begin{array}{l}\text { Step - 4 } \\
\text { Share }\end{array}$ & $\begin{array}{l}\text { A pair of student is asked randomly to share their opinion to all } \\
\text { student, the activity should be guided by the teacher. }\end{array}$ \\
\hline $\begin{array}{l}\text { Step - 5 } \\
\text { Appreciation }\end{array}$ & The student is assessed individually and in group \\
\hline
\end{tabular}

\subsection{The Type of Study}

\section{THE METHOD OF RESEARCH}

This study is a developmental research adopted 4D Thiagarajan development model. According to Sugiyono (2011:407) 4D Thiagrajan Development Model usually applied to obtain a certain product also possibly to test its effectiveness. This study is oriented to a product development where its improvement is described as accurate as possible and at last the product is evaluated. The development process is correlated with activity on each development stage. Beside have development its instrument and material teaching there is also improved such as : SAP, the questions at once assess its parameter numbers on population and its meaning, activity sheet, observation sheet of activity, observation sheet of teacher's activity, respond sheet of student, and validity sheet of instrument and a valid and practical learning material.

\subsection{Subject and Object}

The subject to this study are those students attendant to Semester VI of Mathematics Department FMIPA Universitas Negeri Medan involved 58 students, still the object such 
as: learning material, Lecturing Unit (SAP), Score Instrument, Activity sheet of student, assignment sheet of student, it should determine parameter of population and meaning.

\subsection{The Development Model of Material}

The development model to adopt is 4-D model invented by Thiagarajan, Semmel, and Semmel modified already into four steps namely : first step is to define, second is to design, and the third is to develop, and the last is to disseminate.

\subsection{The Method and Stage of Research}

In details of 4-D Thiagarajan development model are as followings :

\subsubsection{To define stage}

The objective of defining is to determine and to define the requirements of study, need to analyze the purpose and limitation of material. On this stage comprising 5 main steps, they are (a) to analyze a fore-end; (b) analyze the student, (c) to analyze their tasks; (d) to analyze the concept, and (e) to formulate the purpose of study.

\subsubsection{To Design Stage}

The design stage is aimed at designing the learning tools. There are four steps done on this phase, namely : (a) to arrange standard test (constructing criterion-referenced test; (b) media selection refers to the characteristic of material and the purpose of learning, (c) format selection, namely to observe the formats of material available and to decide the format need to develop then, (d) make an initial design refers to the format selected.

\subsubsection{The Development Stage}

The development stage is to generate a development product done in two stages, namely : (1) expert appraisal then its revision, (2) developmental testing. The purpose conducting this development is to generate a final instrument and study material after having revision refers to inputs given by the experts and data result of testing.

\subsubsection{Dissemination Stage}

The dissemination stage constituted the last step of development. Dissemination stage is done to promote a development product to be acceptable by user, either individually, in group, or system. Producer and distributor should be selective and cooperated to create a properly material. Dissemination can be done in other class-room aimed at knowing the effectiveness of using the tools of the learning process. The dissemination can be done through a transmission process to the learning practitioners concerned in a certain forum. The dissemination alike aimed at having inputs, corrections, suggestions, evaluation, perhaps in order to improve the last product of development and gain a ready to adopt by others.

\subsection{The Technique of Data Collection}

The instruments to use in this research are : (1) validity sheet, (2) sheet to expert appraisal or practitioner about its practical and effectiveness of material; (3) observation sheet; (4) questionnaire sheet of student and teacher; and (5) test of attendance.

In order to indicate validity of learning tools is used a descriptive statistic analysis based on average score of each learning tools that has been validated. To determine this total validity aspect, the following should be done. 
1. Make, and recapitulate data appraisal of validity its learning tools into table, comprising of : Aspect $\left(\mathrm{A}_{\mathrm{i}}\right)$, indicator $\left(\mathrm{I}_{\mathrm{i}}\right)$, and Value $\left(\mathrm{V}_{\mathrm{ii}}\right)$ of each expert. These aspects can be seen on sheet of validity of tools as attached.

To determine its average score from expert to each indicator with formulation:

$I_{i}=\frac{\sum_{j=1}^{n} V_{j i}}{n}$

(Sinaga, 2007: 160)

Notes :

$\mathrm{V}_{\mathrm{ji}}$ is data of score by appraiser of the-j over indicator to-i, $\mathrm{n}$ is amount of appraiser (expert and practitioner)

2. To determine average score to each aspect with formulation :

$$
A_{i}=\frac{\sum_{j=1}^{m} I_{i j}}{m} \text { (Sinaga, 2007: 160) }
$$

Notes :

$A_{i}$ is average score to aspect of the- $i$,

$\mathrm{I}_{\mathrm{ij}}$ is average to aspect the-i indicator the-j,

$\mathrm{m}$ is the amount of indicator to aspect the-i

3. To determine score $\mathrm{Va}$ or value in average total of average score to all aspect with the formulation :

$$
V a=\frac{\sum_{i=1}^{n} A_{i}}{n} \quad \text { (Sinaga, 2007: 160) }
$$

Notes :

$\mathrm{Va}$ is average score total to all aspect

$A_{i}$ is average score to aspect the $-i$,

$\mathrm{n}$ is amount of aspects

Thence, value Va or score average this total is referred to interval determination of validity rate of its learning tools of problem based as developed, as showed in the following Table 3.

Table 3. Criterion of Validity Rate

\begin{tabular}{|l|l|l|}
\hline No & $\begin{array}{l}\text { Va or Average total } \\
\text { Score }\end{array}$ & Criterion Validity \\
\hline $\mathbf{1}$ & $1 \leq \mathrm{Va}<2$ & Not valid \\
\hline $\mathbf{2}$ & $2 \leq \mathrm{Va}<3$ & Less Valid \\
\hline $\mathbf{3}$ & $3 \leq \mathrm{Va}<4$ & Moderate Valid \\
\hline $\mathbf{4}$ & $4 \leq \mathrm{Va}<5$ & Valid \\
\hline $\mathbf{5}$ & $\mathrm{Va}=5$ & Very Valid \\
\hline
\end{tabular}

Criterion indicated that the learning tool as developed in a good validity rate if a minimal validity rate achieved is in valid rate. If the validity achieved rate under valid, it must need revision according to correction of expert. Further, required need validity activity. After having a valid category, perhaps the tool has been reliable to test in field. 
The analysis to data of activity is done by calculating percentage of observation by student, namely with :

$$
\text { Percentage activity of student }=\frac{\text { Frequency each aspect }}{\text { Amount of student all aspect }} \times 100 \%
$$

It is given $5 \%$ only as tolerated limit to ideal time. Determination of criterion effectiveness to activity is based on ideal time achievement decided when arrange the plan of learning problem based.

The respond of student is analyzed by calculating percentage amount of student in positive reply on each category as in questionnaire. Criterion decided sounding the student have a positive respond upon the learning tool as developed is whenever the percentage in amount student with positive respond to each category or aspect noted $(\mathrm{PRS}) \geq 80 \%$.

Having classical completeness (PKK) is obtained after calculating percentage amount of student got completed individually, for its percentage can be done by formulation :

$$
\text { PKK }=\frac{\text { Amount student completed in studying }}{\text { Total amount of student all }} \quad \text { x } 100 \%
$$

Any class-room is classified got completed in studying if PKK ) $\geq 85 \%$ (Trianto, 2011:241).

Acknowledgment to use in autonomous instrument in studying is arranged bases to Likert scale. The result of measuring in autonomous to study is with score. The instrument as already filled then seeking its total score, so each student get score. Further, to find average score of all student and its standard deviation. The category result of calculation can be seen on Table 4 with its standard.

Table 4 : Category get autonomous in studying

(Source: Mardapi, 2008: 123)

\begin{tabular}{|l|l|}
\hline Score & Category \\
\hline $\mathrm{X} \geq \overline{\mathrm{X}}+\mathrm{SB}_{\mathrm{X}}$ & Very high \\
\hline$\overline{\mathrm{X}}+\mathrm{SB}_{\mathrm{X}}>\mathrm{X} \geq \overline{\mathrm{X}}$ & High \\
\hline$\overline{\mathrm{X}}>\mathrm{X} \geq \overline{\mathrm{X}}-\mathrm{SB}_{\mathrm{X}}$ & Lower \\
\hline $\mathrm{X}<\overline{\mathrm{X}}-\mathrm{SB}_{\mathrm{X}}$ & Very low \\
\hline
\end{tabular}

Notes :

$\overline{\mathrm{X}} \quad$ is average score of student

$\mathrm{SB}_{\mathrm{x}} \quad$ is standard deviation of score in all student in one class room

$\mathrm{X} \quad$ is score rate obtained by student

\section{THE RESULT OF RESEARCH}

The objective of this study is to develop a learning tool be valid and effective using a learning tool of PMB model oriented. The result of development such as available Attendance Unit (SAP), book of student (BS), working sheet of student (LKS), thinking 
ability test in attendance of Demographics (TKBK) and autonomous studying questionnaire $(\mathrm{AKB})$.

\subsection{The Result of Observation by Student}

The result of observation by student on tri-out II is shown on Table 5. On this table can be seen that percentage activity of student on each category for the first session are $27,55 \% ; 12,98 \% ; 37,03 \% ; 13,74 \% ; 7,34 \%$ dan $1,43 \%$. The percentage activity of student to hear and know explanation of teacher / friend on session 1 noted $26.98 \%$ in 100 minutes. This percentage is obtained from the result divided frequency activity of 14 students to category (a), namely 69 to 252 and multiplied $100 \%$. Number of 252 is obtained from the result divided much time used to conduct the attendance on session 1 , namely 90 minutes with time unit of observation, namely 5 minutes and multiply to amount of student observed namely 14 .

Table 5 : The Summary Result of Observation Activity of Students in Tri-out II

\begin{tabular}{|c|c|c|c|c|c|c|c|}
\hline \multirow{2}{*}{$\begin{array}{l}\text { Activi } \\
\text { ty }\end{array}$} & \multicolumn{2}{|c|}{ Session 1} & \multicolumn{2}{|c|}{ Session 2} & \multicolumn{2}{|l|}{ Session 3} & \multirow{2}{*}{$\begin{array}{l}\text { Avera } \\
\text { ge } \\
(\%)\end{array}$} \\
\hline & $\begin{array}{l}\text { Frequen } \\
\text { cy }\end{array}$ & $\begin{array}{l}\text { Percentage } \\
(\%)\end{array}$ & $\begin{array}{l}\text { Frequen } \\
\text { cy }\end{array}$ & $\begin{array}{l}\text { Percentage } \\
(\%)\end{array}$ & $\begin{array}{l}\text { Frequenc } \\
\mathrm{y}\end{array}$ & $\begin{array}{l}\text { Percentage } \\
(\%)\end{array}$ & \\
\hline A & 69 & 27,38 & 65 & 26,85 & 91 & 28,43 & 27,55 \\
\hline B & 32 & 12,69 & 28 & 11,57 & 47 & 14,68 & 12,98 \\
\hline C & 97 & 38,49 & 91 & 37,60 & 112 & 35,8 & 37,03 \\
\hline D & 36 & 14,28 & 35 & 14,46 & 40 & 12,5 & 13,74 \\
\hline $\mathbf{E}$ & 15 & 5,95 & 20 & 8,26 & 24 & 7,81 & 7,34 \\
\hline $\mathbf{F}$ & 3 & 1,19 & 3 & 1,23 & 6 & 1,87 & 1,43 \\
\hline Total & 252 & 100 & 242 & 100 & 320 & 100 & 100 \\
\hline
\end{tabular}

Notes :
a) Pay attention/ hear to explanation of teacher / friend
b) Read/ know problem contextual in book / LKM
c) Solving the problem/ find the way out and how to take over
d) Have Discussion/ ask friend or teacher
e) Take conclusion by procedure or concept and present the result of working
f) Behavior of student as not relevant to TPS model

With the same way obtained percentage of having activity to the learning and teaching on other activity category on each session. The time spent and amount of student observed to each session is not always in same (in this matter is 100 minutes or 150 minutes, while the student to observe in session 1 is amount 14 students, to session 2 noted 13 students, while to session 3 amount 12 students) so determination to percentage of each activity category is also not same, it depends on time of attendance and amount of students to observe in each session. Further, average percentage of time activity of student in each category for three times session are $27.38 \%, 12.69 \%, 38.49 \%$; $14.28 \%, 5.95 \%$, and $1.19 \%$. 


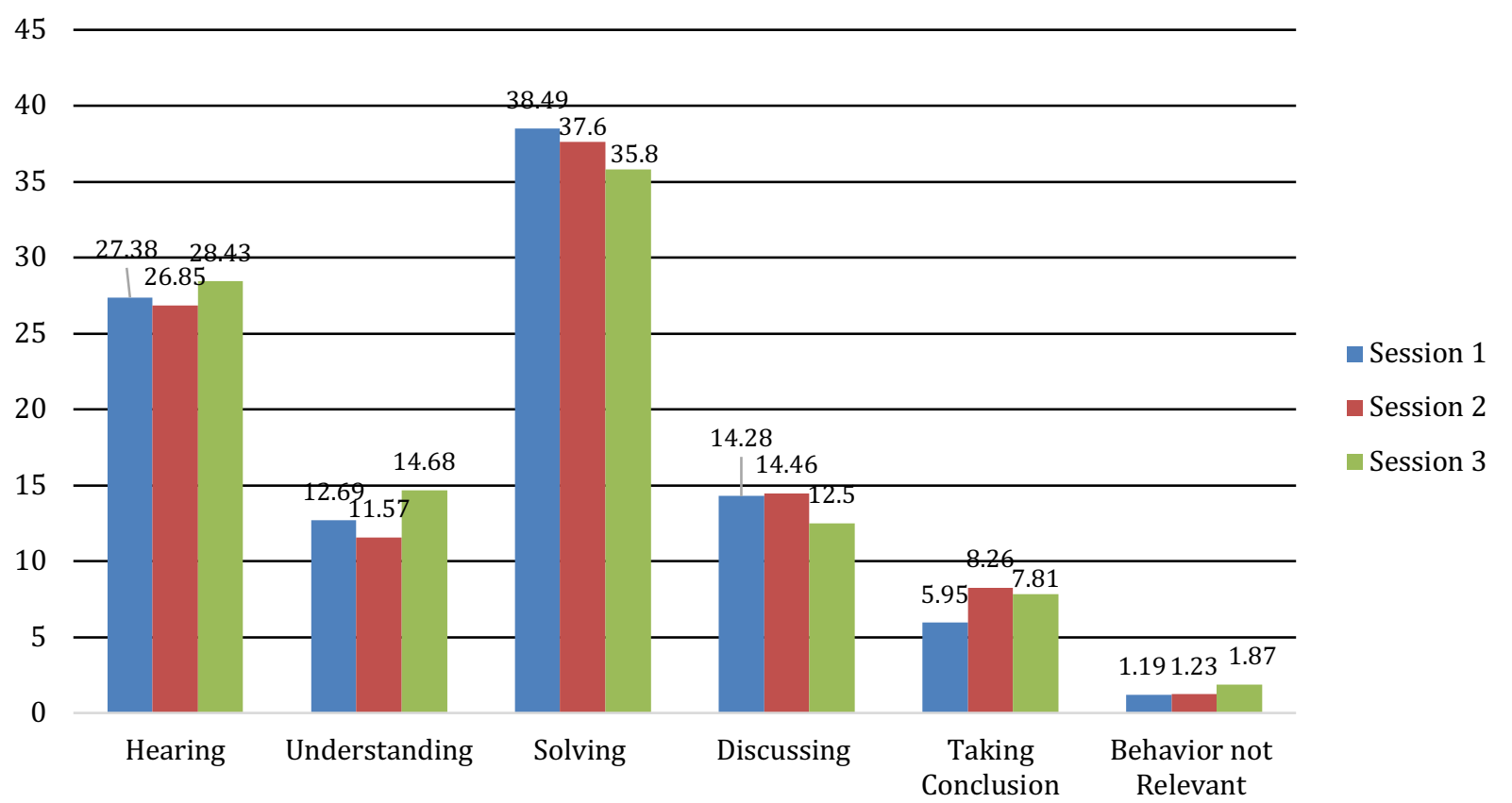

Fig 1: Graphic Observation to Activity of Student on Tri-out of Session

\subsection{The Result of Student's Respond Questionnaire}

The questionnaire of students' respond is given on last of each session. Tabulation and percentage result of questionnaire on Tri-out II shall yield average percentage result of their respond as displayed on Table 8. Based on data available is obtained average percentage of amount student expressing be pleases on the component and activity of attendance namely $93.52 \%, 91.38 \%, 96.55 \%, 93.1 \%$, and $93.1 \%$. This percentage is also obtained from the result dividing total percentage positive respond on all three sessions to tri-out II with many sessions.

In whole, average percentage respond of student on each aspect are as following: (1) 95.1\% students expressing be pleasure on the component and their attendance; (2) 90.85\% students expressing the component and the attendance is newly for them; (3) 92.1\% students expressing out willingness to attend the class of Demographics with other material; (4) 90.7\% expressing out language in use to books and LKM is clear; and (5) $94.1 \%$ students expressing out interested with book appearance and to LKM available. The percentage average total respond of student in positive on the tri-out-II noted $92.58 \%$. If the result of this analysis refers to criterion as previously decided may take conclusion that their respond upon the component of activity to attendant of TPS model oriented is positive.

\subsection{The Result of Test Ability Attending Demographics}

The result of test ability attending Demographics on the tri-out II may yield output as Table 6. In this table can be seen average result of ability attending the Demographics as on tri-out II is 3.16 by maximum score 4.0. Percentage of student completed is noted $91.37 \%$. this percentage is obtained by dividing frequency of student completed with 52 to total students namely 58 and multiply 100\%. If refers to Chapter III, this percentage has fulfilled a classical completeness as decided namely $\geq 85 \%$. Therefore, it is concluded that a classical completeness criterion has fulfilled. 
Table 6 : Test Ability in Attending Demographics as On Tri-out II I

\begin{tabular}{|l|l|l|l|}
\hline Category & Frequency & Percentage (\%) & Average \\
\hline Completed & 52 & 91,37 & 3,16 \\
\hline Not Completed & 6 & 8,63 & \\
\hline Total & 58 & 100 & \\
\cline { 1 - 3 } & &
\end{tabular}

\subsection{The Result in Questionnaire of Student Autonomous}

The result in questionnaire of their autonomous to study as on tri-out II can be seen on the conclusion taken by questionnaire in autonomous to study as obtained, it is shown on Table 7 as following.

Table 7 : The Result in Questionnaire of Their Autonomous on Tri-out II

\begin{tabular}{|c|c|c|c|}
\hline Category & Frequency & Percentage (\%) & Average \\
\hline Very High & 9 & 15,51 & \multirow{4}{*}{56,42} \\
\hline High & 40 & 68,96 & \\
\hline Low & 6 & 10,34 & \\
\hline Very Low & 3 & 5,17 & \\
\hline Total & 58 & 100 & \\
\hline
\end{tabular}

By the table can be seen that average in autonomous to study of student is noted 56.42 by maximum score 72 . Percentage autonomous to study by student with very high category is noted $15.51 \%$, for this rate is obtained from dividing to many students with very high category namely 9 with many student of totally 58 and to multiply $100 \%$. The other category rate is also obtained in the same way.

\section{a Analysis Comparison of Result to Tri-out I and II}

Following conducted trial in two times, the data obtained on both trials have been analyzed mainly then to see the result of correction done. In this case to show comparison of activity student, their respond, existing of program of attending in Demographics and let see after it.

Comparison Activity of Student

Average percentage of times to activity in each category as long as three times session either to trial I or II as shown in Table 8 below.

Table 8 : Average Percentage of Activity by Students

\begin{tabular}{|l|l|l|}
\hline \multirow{2}{*}{ Activity } & \multicolumn{2}{|c|}{ Percentage Activity (\%) } \\
\cline { 2 - 3 } \multicolumn{1}{|c|}{ Trial I } & \multicolumn{1}{c|}{ Trial II } \\
\hline A & 24,13 & 25,86 \\
\hline B & 22,41 & 24,13 \\
\hline C & 27,58 & 20,68 \\
\hline D & 12,06 & 12,06 \\
\hline E & 10,34 & 10,34 \\
\hline F & 3,44 & 6,89 \\
\hline Total & 100 & 100 \\
\hline
\end{tabular}

Average activity to each category on Trial I are $24.13 \%, 22.41 \%, 27.5 \%, 12.06 \%, 10.34 \%$ and $3.44 \%$. This average percentage is obtained by the result of dividing total percentage 
activity to each category with the amount sessions, namely 3 sessions. For instance, average activity (a) on trial I namely $24.13 \%$ obtained by total percentage of activity (a) on the three sessions namely $22.41 \%, 27.58 \%, 12.06 \%$ and divided by 3 . Average to other activity can be obtained by the same way.

Average percentage of time spend by student in conducting activity can be represented as in Figure 2. The greatest time percentage spent by student as long as having learning - studying is noted category (c) namely solving the problem / find its way and reply to the problem. Percentage of this category as on Trial I is $27.58 \%$ and on trial II is noted $27.55 \%$. This indicated during conducting the attending, those students dominantly spend time for solving or find resolution problem as on LKM.

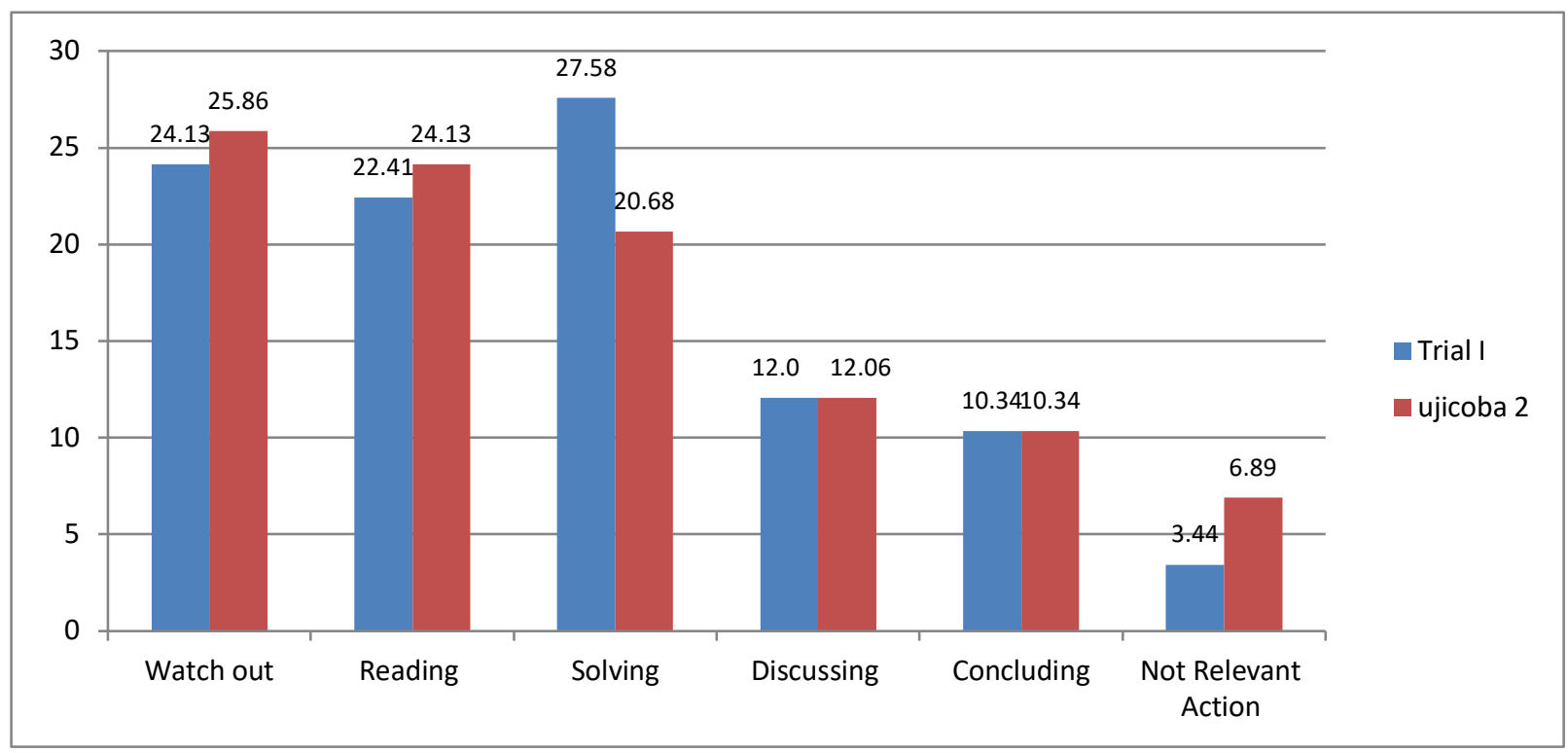

Figure 3 : Diagram Percentage of Time Activity by Student

The average percentage of time as student conducting activity of watching / listening the attendance is noted $24.13 \%$ on the trial I and $25.86 \%$ on Trial II of the times provided on each session. Percentage times of this activity is on ideal time tolerated interval as previously decided. Average percentage of times as student conducting of reading/ understand contextual problem in books / LKPM is noted $22.41 \%$ as on Trial I and $24.13 \%$ on trial II. This percentage is also yet on ideal time tolerated interval as decided. Average percentage of activity by student to discuss/ ask question to friend or teacher, namely $27.58 \%$ on trial I and got $20.68 \%$ on trial II. Percentage times of this activity is also on ideal times tolerated interval decided. Average percentage activity by student taking conclusion in procedure or concept and present the results they are $12.06 \%$ on trial I and $12.06 \%$ on trial II. Percentage times of this activity is on ideal time tolerated interval as decided. While average percentage of times by student conducting not relevant activity with attending is $3.44 \%$ on trial I and $6.89 \%$ on trial II. This indicated that as long as attending to each session is always available student conducting activity is not relevant with attending. Meanwhile, this percentage is still on ideal time tolerated interval as decided.

In addition, if average percentage of time to conduct activity is referred to criterion of achieving percentage ideal time in activity by student as decided is concluded that percentage time in activity of student has already fulfilled criterion gaining percentage of time in ideal as decided. 


\section{Comparison Respond of Student}

Average percentage respond of students on trials is presented on Table 9. By this table can be seen that by five aspects as student ask got increasing positive respond. For instance, aspect of pleasure on the component of attending got increased $93.1 \%$ up to 94.82\%.

Tabel 9. Rerata Persentase Respon Mahasiswa

\begin{tabular}{|l|l|l|l|}
\hline No. & Aspect & Trial I (\%) & Trial II (\%) \\
\hline 1. & Pleasure on Component of Attending & 93,10 & 94,82 \\
\hline 2. & Newly on component of attending & 91,37 & 93,10 \\
\hline 3. & Willingly to attend another class & 96,55 & 96,37 \\
\hline 4. & Certainly in language & 94,83 & 96,55 \\
\hline 5. & Legibility of appearance & 91,37 & 89,65 \\
\hline
\end{tabular}

Average percentage in respond by student on the tool and atmosphere of attending can be represented as Figure 3 as following, from thence can be seen that average percentage respond of student on both trials is over $80 \%$. In refers to Chapter III, this percentage has fulfilled criterion as decided. The greatest increase is on second aspect (updated on component of attending) and on fifth (interested with appearance). This occurred on draft III as correction to draft II, it means found weaknesses on draft II has been corrected bases the result on trial I.

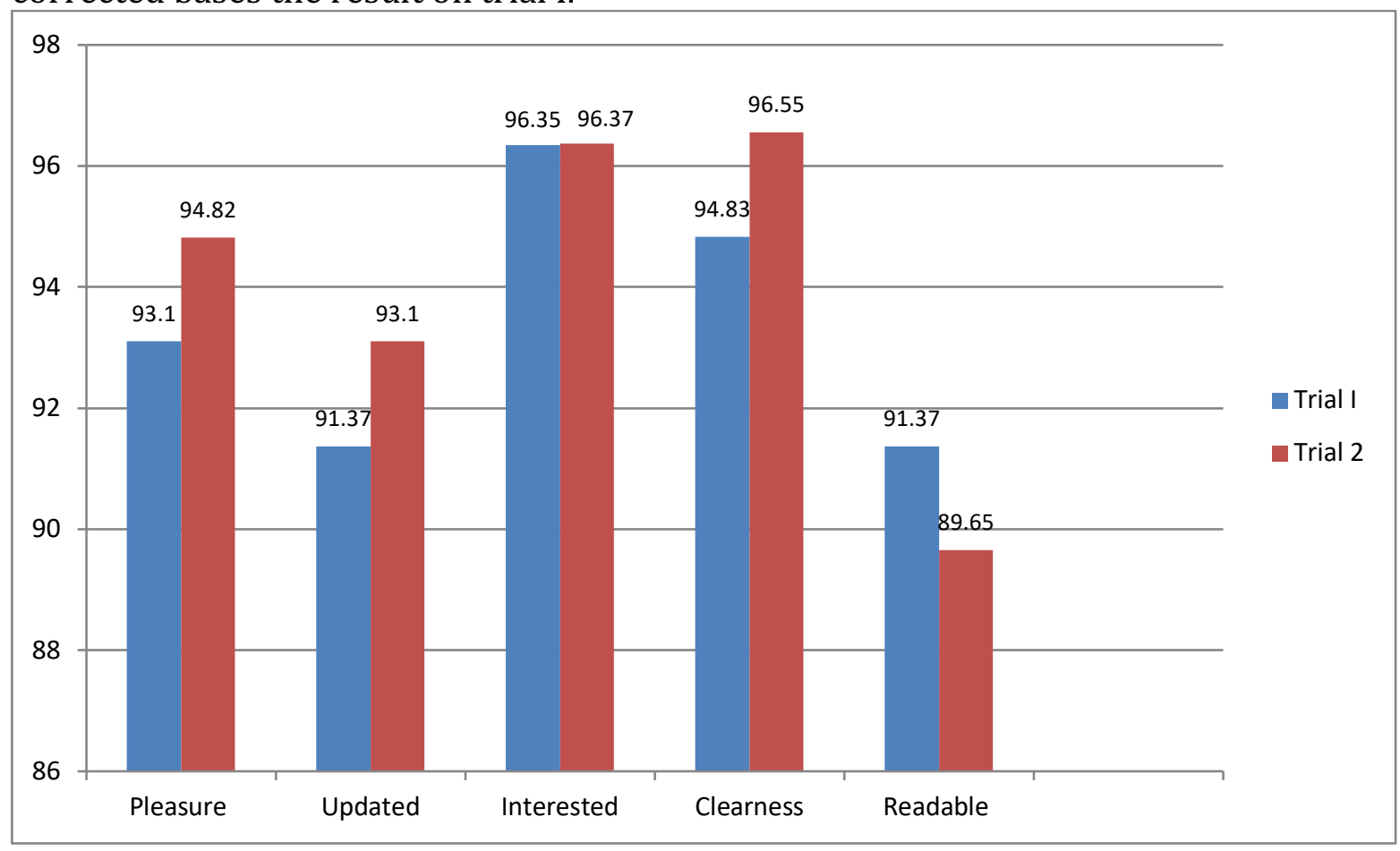

Figure 4 : Comparison Respond of Students

\section{Comparison Ability of Result Attending on Demographics}

Comparison result of test ability after attending in Demographics is presented on Table 10 . By this table seen that average ability of thinking in high rate as on trial I is 2.98 , while on trial II is 3.25 point. Percentage of student completed on trial I is $86.20 \%$ and not completed is $13.80 \%$. Refers to criterion of completeness, percentage of completeness noted $87.93 \%$ and this not fulfilled to classical completeness as decided of $\geq 85 \%$, whereas to trial II, percentage of student with complete is noted $87.93 \%$ and not 
complete $12.07 \%$. Percentage completeness of $86.57 \%$ and this fulfilled a classical completeness as decided.

Table 10 : Comparison Result of Test ability in Attending Demographics

\begin{tabular}{|l|l|l|}
\hline \multicolumn{1}{|c|}{ Remarks } & \multicolumn{1}{c|}{ Trial I } & \multicolumn{1}{c|}{ Trial II } \\
\hline Average & 2,98 & 3,25 \\
\hline Percentage of Student with complete & 86,20 & 87,93 \\
\hline Percentage student not completed & 13,80 & 12,07 \\
\hline
\end{tabular}

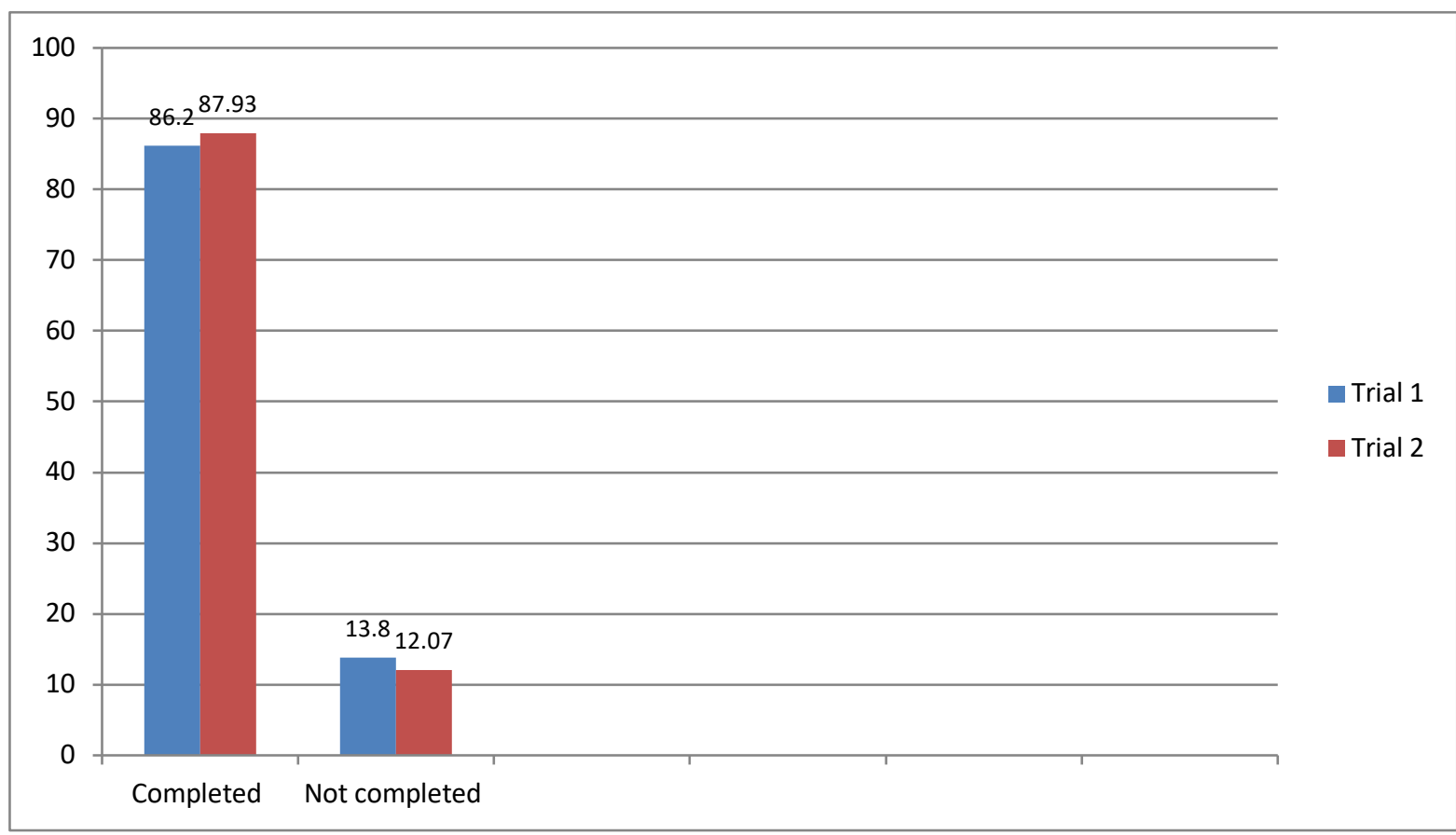

Figure 5 : Representation of Classical Complete On Trial I and II

Comparison result of ability of program attending the Demographics is represented in Figure 5. By this figure is seen that got increasing in high on percentage to student completed in studying. The increasing percentage of complete to trial I to Trial II is noted $1.73 \%$. If seen by average as obtained by student, the increasing occurrence in 0.27 point from maximum score of 4 .

\section{Comparison in Autonomous to Study}

Summary in autonomous by student to study obtained is shown on Table 11. By this table seen average autonomous by student in studying as on trial I is noted 46.26, whereas on trial II is 56.42. The average is obtained by dividing total score of all students to the amount of student. Percentage of student on trial I with autonomous category in very high to study is $18.18 \%$, with high is $21.05 \%$, lower $45.45 \%$ and very low $9.09 \%$. Percentage of student in category very high noted $18.18 \%$ is obtained from amount of student included category autonomous to study with very high (in this case 6) is divided amount students namely 33 and to multiply $100 \%$. Whereas, percentage of student to trial II with category in autonomous to study in very high $21.05 \%$, high $23.68 \%$, lower $47.37 \%$ and very low $5.17 \%$. 
Table 11: Summary in autonomous in Attending

\begin{tabular}{|l|l|l|}
\hline \multicolumn{1}{|c|}{ Remarks } & \multicolumn{1}{c|}{ Trial I } & \multicolumn{1}{c|}{ Trial II } \\
\hline Average & 46,26 & 56,42 \\
\hline Percentage student in category very high (\%) & 18,18 & 21,05 \\
\hline Percentage student in category high (\%) & 27,27 & 23,68 \\
\hline Percentage student in category lower (\%) & 45,45 & 47,37 \\
\hline Percentage student in very low (\%) & 9,09 & 5,17 \\
\hline
\end{tabular}

Representative in category autonomous to student in studying is shown on Figure 5.5. By this program seen that on trial II occurrence increasing up to category very high and lower. The increasing up however is obtained by reducing percentage of student in category high and very low. Having increased on category very high is $2.87 \%$ and on category lower is $3.92 \%$.

On the last stage of development is obtained a field trial there is gained a final attending tool. This final tool comprising of SAP, LKPM, books, test ability of thinking in very high and with questionnaire autonomous to student by student. This final tool is presented successively already booked.

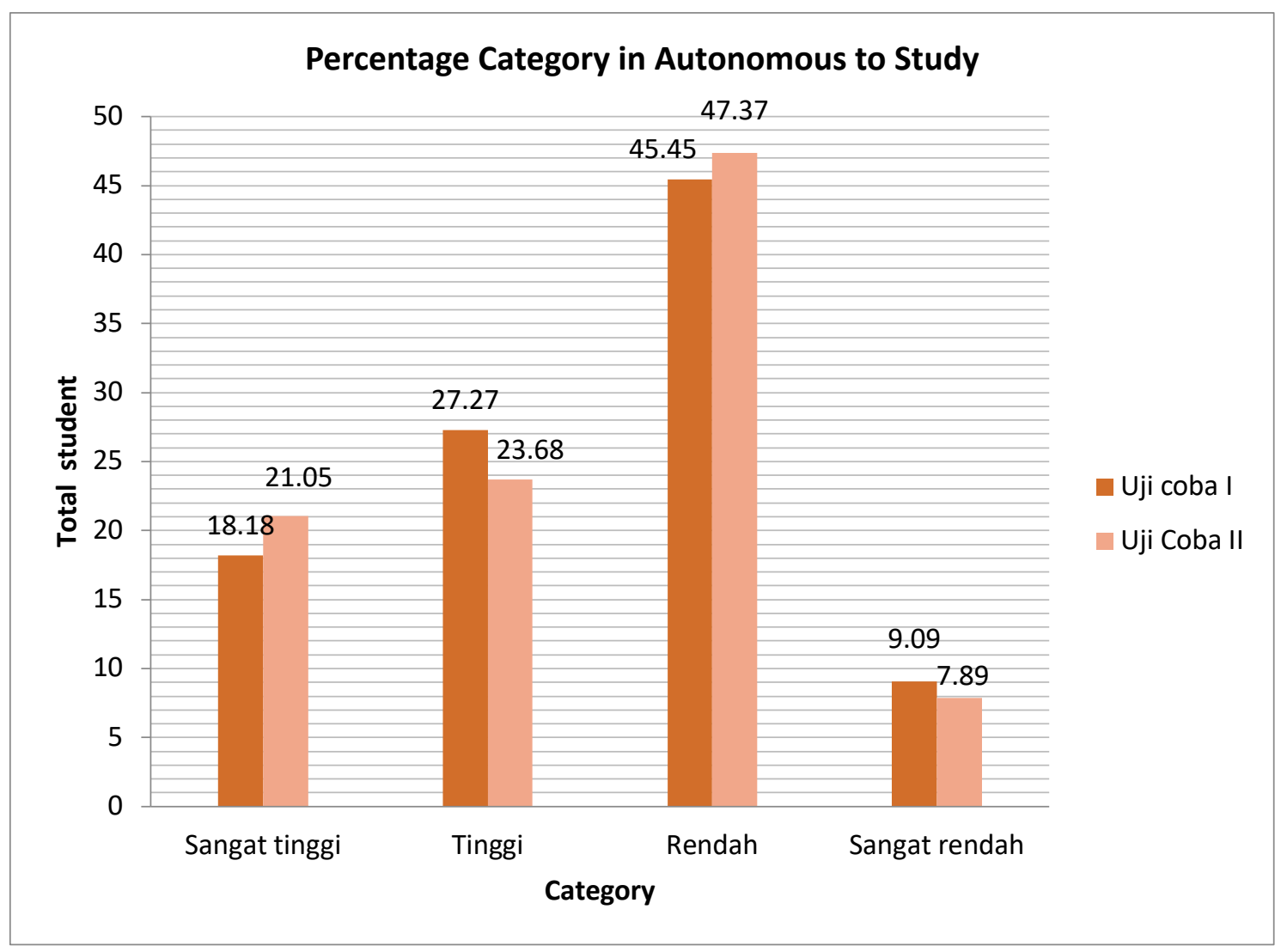

Figure 6 : Percentage Category in Autonomous

Refers to result of research in validity, practical, and effectiveness of learning tool on Demographics as developed and finding as long as conducting the activity, is obtained some conclusions as the answer to formulation of problems as submitted. 
The conclusions as obtained are as followings :

1. The learning tool as developed data based with a learning model of TPS on subject Demographics to Mathematics Study Program in FMIPA Unimed has fulfilled criterion of validity. The experts urged average score total validity to a plan of learning implementation (RPP) is noted 4.36 with criterion valid, guidance book of teacher (BPG) noted 4.13 with criterion valid. Book to attendant (BPD) noted 4.16 with criterion valid, activity sheet of student (LKPD) noted 4.38 with criterion valid and test ability of solving problem (TKPM) noted 4 with criterion valid. Whereas, based instrument trial also included the four points of test ability to solving problem with category valid.

2. Upon the learning tool as developed in data based with a learning model TPS on Demographics on Study Program Mathematics FMIPA Unimed has fulfilled criterion be practical. Bases to aspect of practical on the result of trial in field, average score to administer the learning tool is on category implemented very good $\left(4 \leq R_{K} \leq 5\right)$ namely 4.33 . In respond of student upon the learning tool as developed is in category very positive $\left(R_{F D} \geq 85 \%\right)$ namely $89.31 \%$; and respond of teacher upon the learning tool as developed is in category very good $\left(4 \leq R_{C} 5\right)$ namely 4.13.

3. Upon the learning tool as developed in data based with a learning model TPS on Demographics on Study Program FMIPA Unimed has fulfilled criterion validity there is fulfilling already criterion effectiveness. The effectiveness of learning tool is mentioned as the followings :

a) On the result of first field trial, based on effectiveness aspect : (1) average score post-test is 81.31 , with percentage achieving $76.92 \%$ with total attendant completed is 20 students. Achieving classically on result of test ability on solving in mathematics by those students is noted $76.92 \% \leq 85 \%$ (KKM), so achievement the result in ability on solving to mathematics not achieved classically; (2) capability of teacher to manage the learning as long as three sessions average score by two observer namely 2.96 is on category "not good" $(2 \leq N K G<3)$, bases criterion of effectiveness, is noted effective if average ability of teacher to all session achieved criterion minimal is good $(3 \leq N K G<4)$, so capability of teacher to manage the learning is noted not yet effective; (3) activity of students is on criterion limited effectiveness of learning due to percentage of activity to each category of observation and each session is on criterion limited effectiveness in learning, so the learning tool not got any revision bases the result of observation in activity. By the three indicator of effectiveness on the field trial as first is concluded that the learning tool is not effective yet and need revision and also should be done field trial in second.

b) On the result as second trial, bases to effectiveness aspect : (1) average score posttest is noted 94.38 , with percentage achieved of $96.15 \%$ with total attendants in completed is 25 students. Achieving classically on result of test ability of solving problem on mathematics is noted $96.15 \% \geq 85 \%$ (KKM), so the achievement result of studying mainly solving the problem in mathematics has already achieved classically; (2) ability of teacher to manage the learning as long as three sessions average score by two observers namely 3.67 is noted category "good enough" ( $3 \leq N K G<4$ ), bases criterion effectiveness, is considered effective if average ability of teacher to all sessions achieving minimum criterion of good ( 3 $\leq N K G<4$ ), so ability of teacher to manage the learning is already effective, (3) activity of student is on criterion limited effective to learning due to percentage of activity on each category of observation and each session is on criterion limited 
effectiveness in learning, so the learning tool got no any revision. By the three category of effectiveness on field trial in secondly concluded that the learning tool is already effective.

Improving result of ability in attending Demographics data based with learning model TPS as on study program Mathematics of FMIPA Unimed is seen from the average score of achieving ability as result of attending Demographic, percentage classical achievement of $\geq 85 \%$, and average each indicator of ability on solving problem. On the first field trial, with result of post-test ability to solving problem on Mathematics is obtained the average score noted 81.31. Whereas on the trial in field secondly, by the result post-test ability of solving problem on Mathematics is obtained average score noted 94.38. It is noted increased result in post-test as field trial in first to the second field trial is noted 13.07 points. Further, on the first trial percentage classical achievement ability of solving problems on mathematics is obtained its percentage of $76.92 \%$. Whereas on second field trial, percentage ability in solving problem is obtained its percentage of 96.15. It means, increased up percentage achievement classical on first field trial to the second is $19.23 \%$. The last, on the first field trial, average score upon the four indicators, namely understanding the problem, arrange the solution, administer to solving problem, and check-recheck namely noted $90.00 ; 81.89 ; 72.40$; and 70.91. Whereas on the second field trial, average score upon the four indicators, namely to understand, arrange the solving problem, administer the solving, and recheck namely each of 95.38; 94.95; 91.15; and 93.75. Still, there is increasing average score upon the four indicators on the first field trial to the second field trial namely each $5.38 ; 13.06 ; 18.75$; and 22.84 points.

\section{SUGGESTIONS}

The learning tool as obtained still need to trial yet mainly to other students of Semester VI Study Program Mathematics FMIPA Unimed with various condition in order to obtain a Demographic is truly qualified on the learning tool. In the learning as designed by team, with teacher and other stakeholder must conform to the students involved within one group so the process of discussion can process maximally. In conducting revision to an attending unit (SAP), text book of student (BTPM), and activity sheet of attendant on Demographic (LKPDM) and activity sheet of attendants (PKHPM), by the trial I to another trial, the research should never reject complexity of problem. But, still need revision anyway, see guidance of solving the problem, and it must be conducted according to field condition well.

\section{References}

Adioetomo, \& Moertiningsih, S, 2015, Bonus Demografi. Menjelaskan Hubungan Antara Pertumbuhan Penduduk Dengan Pertumbuhan Ekonomi. Pidato Disampaikan pada Upacara Pengukuhan Jabatan Guru Besar Tetap Dalam Bidang Ekonomi Kependudukan pada Fakultas Ekonomi Universitas Indonesia, Jakarta.

Akker, J. van den. 1999. Principles and Methods of Development Research. Dalam Plomp, T; Nieveen, N; Gustafson, K; Branch, R.M; dan van den Akker, J (eds). Design Approaches and Tools in Education and Training. London: Kluwer Academic Publisher.

Amir, M.T. 2009. Inovasi Pembelajaran Pendidikan Melalui Problem Based Learning: Bagaimana Pendidik MemberdayakanPemelajar di Era Pengetahuan. Jakarta.

Bouge, Donald J. 2016. Principles of Demography. New York. John Wiley \& Sons. 
Fachrurazi. 2011. Penerapan Pembelajaran Berbasis Masalah untuk Meningkatkan Kemampuan Berpikir Kritis dan Komunikasi Matematis Siswa Sekolah Dasar. Jurnal: tidak diterbitkan.

Hillman, W. 2003. Learning How to Learn: Problem Based Learning. Australian Journal of Teacher Education, 28 (2): 1 - 10.

Jalal, Fasli, 2014, Optimalisasi Pemanfaatan Bonus Demografi.Jakarta: BKKBN, Jakarta.

Joko Nurkamto. 2015. Menyiapkan Generasi Emas Indonesia 2045. FKIP Universitas Sebelas Maret, jokonurkamto\&@gmail.com

Kominfo, 2015, Siapa Mau Bonus, Peluang Demografi Indonesia, Jakarta:

Kominfo. Mantra, Ida Bagus, 2015, Demografi Umum, Pustaka Pelajar, Yogyakarta.

Rusli, S., Toersilaningsih, R., Meirida, D., Kurniawan, U. K., \& Setiawan, K. D,2015, Potensi dan Implikasi Bonus Demografi di Provinsi Banten Tahun 2015-2035, Jakarta: Direktorat Analisis Dampak Kependudukan BKKBN.

Shyrock Henry S. and Siegel Jacob S., 2015. The Methods and Materiel of demografhy, Orlando San Diego New York Academics Inc Press.

Siagian Pargaulan. 2012. Prototype bahan ajar demografi. Lembaga Penelitian, Universitas Negeri Medan

Siagian Pargaulan. 2017. International Journal of Innovation in Science and Mathematics. Prototype Teaching Mathematics in Improving Critical Thinking Ability of Senior High School Students.

Padmavathy \& Mareesh. 2013. Effectiveness of Problem Based Learning in Mathematics. International Multidisciplinary e-Journal, 2 (1): 45 - 51.

Rochmad. 2012. Desain Model Pengembangan Perangkat Pembelajaran. Jurnal Kreano, 3 (1): 59 - 72

Rohman \& Amri. 2013. Strategi dan Desain Pengembangan Sistem Pembelajaran. Jakarta: Prestasi Pustaka

Rusman. 2011. Model-Model Pembelajaran: Mengembangkan Peofesionalisme Guru. Jakarta: PT Raja Grafindo Persada

Thiagarajan, S. dkk. 2016. Instructional development for Training Teachers of Exceptional Children A Sourcebook. Minnesota: National Center For Improvement of Educational System.

Trianto. 2011. Mendesain Model Pembelajaran Inovatif Progresif. Jakarta: Kencana Prenada Media Group. 